\title{
LIES ON LABELS, OR CASES OF MISLEADING CONSUMERS ON THE EXAMPLE OF VEGETABLE OILS
}

\author{
Joanna Hernik ${ }^{1}$, Gunta Grinberga-Zalite ${ }^{2}$ \\ ${ }^{1}$ West Pomeranian University of Technology in Szczecin, Poland \\ ${ }^{2}$ Latvia University of Life Sciences and Technologies, Latvia \\ jhernik@zut.edu.pl
}

\begin{abstract}
In 2018, the Polish Trade Inspection in the whole country carried out an assessment of unrefined vegetable oils and olive oils of various categories. First of all, the correctness of marking, physicochemical parameters, storage conditions, traceability of products and their dates of minimum durability were assessed. In total 380 batches of products were inspected. Results of the examination show that producers cheat consumers by providing, for example, untrue nutritional values or false information about dietetic or health traits. The purpose of this article is to determine what consumers should know to verify the correctness of information on product labels independently. The theoretical part of the article was based on the EU regulations analysis regarding vegetable oils properties, including the characteristics of olive oil. The empirical part concerned data from Polish Trade Inspection reports, as well as statistical data on production and sale of oil and olive oil from the portal Statista. In this article methods of documentary research and comparative analysis were used. For the main conclusion it can be assumed that products of poor quality or incorrect labeling can be found in each product category; therefore, consumers should pay attention to such elements as information in their native language, a full list of ingredients, or correct indication of nutritional values.
\end{abstract}

Key words: product labeling, vegetable oils, trade inspection, shortcomings.

\section{Introduction}

More and more often consumers pay attention to the health properties of food and expect that food products will not only provide nutritional value, but also improve their health. It results from the growing awareness of consumers, shaped by promotional campaigns about health, and also by new legal regulations concerning food, especially pro-health and ecological products. Among the applicable regulations, the key one is the Regulation of the European Parliament and the EU Council No. 1151 of 2012 published in the Official Journal (OJ) of the European Union on quality schemes for agricultural products and foodstuffs (OJ L 343/1, 2012). The rules on the labeling of agricultural products and foodstuffs are set out in Directive 2000/13/EC of the European Parliament and of the Council of 2000 on the approximation of the laws of the Member States regarding to the labeling, presentation and advertising of foodstuffs (OJ L 210, 2000).

The 2000 directive specifically defines what product labeling is - according to paragraph 1.3, the labeling covers any words, particulars, trademarks, brand names, pictorial matters or symbol relating to a foodstuff and placed on any packaging, document, notice, label, ring, or collar accompanying or referring to such foodstuff. Thus the label does not have to be placed on the product itself. Moreover, the label cannot mislead the consumer as to the properties of a foodstuff, in particular as to its nature, identity, properties, composition, quantity, durability, origin or provenance, method of manufacture or production (Article 2.1). The label cannot suggest that a foodstuff has any special properties when in reality all similar foodstuffs have those properties. Thus, the directive orders the introduction of rules that apply to labeling which will prohibit using information which might mislead the consumer (OJ L 210, 2000).

In the case of labeling foodstuffs, including edible oils, the producer has to provide: 1) the name under which the product is sold; 2) the list of ingredients; 3 ) the quantity of certain ingredients, such as cereals containing gluten; 4) in the case of prepackaged foodstuffs, the net quantity; 5) the date of minimum durability or the "use by" date; 6) any special storage conditions or conditions of use; 7) the name or business name and address of the manufacturer or packager, or of a seller established within the Community.

The aforementioned directive emphasizes that labeling has to be subjected to adequate regulations, because it enables the consumer to make a conscious choice with full knowledge about the product. Labeling products has also a broader dimension - it allows to protect their originality, and supports fair competition of entrepreneurs on the market (Crescimanno, Di Marco, \& Guccione, 2002).

\section{Materials and Methods}

In February 2018, the Polish Trade Inspection (PIH) published a report on the assessment of commercial quality of unrefined vegetable oils and olive oil in different categories. This report became the basis for this article and it was also a premise for further analyses. Therefore, the empirical material consists of data from the Polish Trade Inspection's reports on the quality of foodstuffs and ways of their labeling in the light of the EU legal provisions. The purpose of this article is to determine what consumers 
should know in order to independently verify the correctness of information on product labels. The empirical part was supplemented with statistical data on the production of vegetable oils and olive oils obtained from the Statista website (https://www. statista.com/). Therefore, methods of documentary research and comparative analysis were used in the article.

Packaging and labeling - functions

The packaging, as M. Zajaczkowski writes, is a product intended for packaging other products (Zajaczkowski, 2002). Of course, the main purpose of the packaging is to protect its contents during transportation and storage, but the packaging can also protect the product against theft or it can have promotional functions. Therefore, packaging should be designed not only in a way to protect the product but also to help sell it.

The functions of packaging depend on the stage of distribution of a product. There is always the protective function, that is, the situation when the packaging protects the product from external factors (for example, from insolation and temperature), or protects the environment against the action of the product (as in the case of chemical products). Before the product reaches the consumer, the logistic function is also important; it consists of the packaging facilitating the processes of transportation, storage, and the sale itself. The informative function is also necessary, as it allows to distinguish between particular products, as well as to determine their origin and purpose. The informative function is connected with the promotional function, assuming that the packaging should not only inform, but also attract the consumer's attention and give them positive associations. Therefore, the packaging is sometimes referred to as the 'silent seller,' advertising the product at the place of sale.

Of course, the function of packaging is associated with its purpose - transport packaging is designed to facilitate handling and storage; collective packaging - storage, unit packaging is supposed to inform and promote, and also make it easier for the consumer to take the product home. Information and promotional markings are placed on various types of labels. The labels inform the buyers and consumers about the characteristics of the products and their production, so that the customers have access to reliable data on those products. They also inform about registered trademarks and obtained certificates. Indirectly, proper labeling of foodstuffs contributes to the development of food production, and as a consequence to the achievement of rural development objectives.

The legal requirements on the content of labels, as it has already been mentioned, were published in Directive 2000/13/EC relating to the labeling, presentation and advertising of foodstuffs (OJ L 109). The document states that a label should contain certain essential elements, as presented in Figure 1. Apart from the elements listed in the figure, the producer can also include other information if that is needed from the consumer's point of view. Therefore, it can be a user's manual, or information about the content of alcohol.

Name, list of ingredients, or storage conditions are all obligatory information, however, EU member states can maintain their national regulations if the EU provisions appear to be too restrictive for some products. The packaging also often contains purely promotional information placed there in the interest of

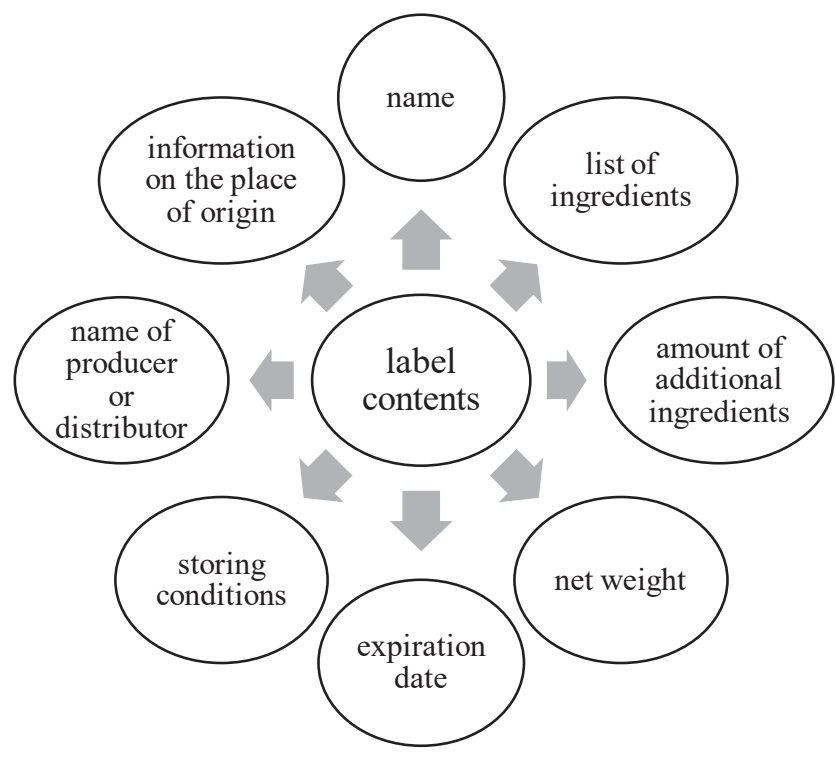

Figure 1. Obligatory information on foodstuff label.

Source: own study on the basis of Directive 2000/13/EC (OJ L 210, 2000). 


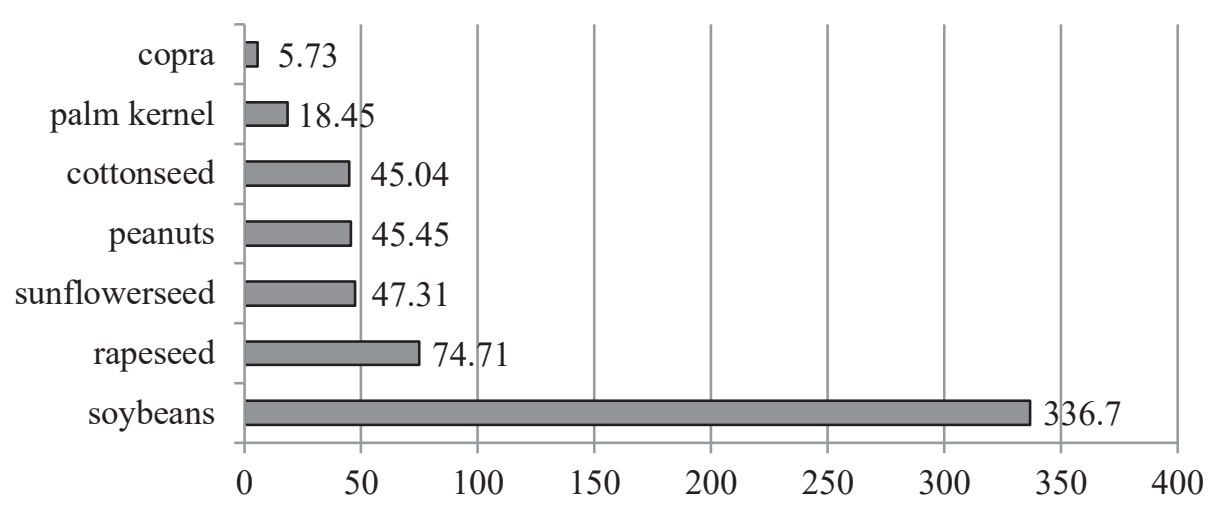

Figure 2. Worldwide oilseed production in 2017/2018, by type (in millions of $\mathrm{t}$ ).

Source: Vegetable oils and fats (n.d.). Retrieved from: https://www.statista.com/study/21986/vegetable-oils-and-fatsstatista-dossier.

the manufacturer, which, however, will not be subject to analysis in this article.

Vegetable oils - characteristic of the category

Any substance in the form of liquid fat can be called oil. Vegetable oils come from plants with high fat content and they can be obtained from seeds, fruits, or pits. For the most part, vegetable oils are used for consumption (Giansante et al., 2017). However, some are used in the production of cosmetics, and some as medicinal products. Oilseed crops include rapeseed, sunflower, flax, soy, poppy, cotton, coconut, hazelnuts, palm oil, cocoa, or European olive.

The global production of oilseed crops is dominated by soy -336.7 million tonnes are produced annually (https://www.statista.com/study/21986/ vegetable-oils-and-fats-statista-dossier/). Rapeseeds (74.7 million t) rank second, followed by sunflower (47.3 million $\mathrm{t}$ ), and peanuts (45.45 million $\mathrm{t})$. This is presented in Figure 2.

The world's leading soy producers include countries such as the USA, Brazil and Argentina. The USA is the largest producer (104 million tons per year), but Argentina is the largest exporter of soybeans, followed by Brazil ('Produkcja soi... '; Kavallari, Maas, \& Schmitz, 2011). The largest exporter of sunflower seeds is Ukraine, while the largest producer of rapeseed oil in the world is China, and in Europe - Germany. The largest producer of palm oil is Indonesia $35 \%$ of world production comes from this country.
An important component of the diet in many countries is olive oil. According to the regulations, several categories can be indicated: extra virgin olive oil, lampante olive oil (extra virgin olive oil whose acidity has exceeded the threshold of $2 \%$ ), refined olive oil, crude olive pomace oil, as well as refined olive oil from olive residue (Commission Regulation (European Economic Community - EEC No 2568/91, Article 1). While the production of vegetable oil in recent years has been systematically growing (from 90.5 million tonnes in $2000 / 01$ to 203.8 million $t$ in $2018 / 19$ ), the global production of olive oil fluctuates from 2.4 to 3.27 million t per year (Figure 3).

In many countries, the consumption of olive oil is growing - in Poland, it has doubled in the last 10 years. In addition, statistical data show that the import of all oil products to Poland in 2018 was larger than in the previous year, so the role of vegetable oil and olive oil in the life of the average Pole is growing.

\section{Results and Discussion}

In 2018, a Trade Inspection report was published, which examined olive oils and other oils in 85 commercial entities (in total, 380 batches of products were tested). The analysis covered 178 batches of olive oil from four categories admitted for retail sale and 202 lots of other vegetable oils, mainly unrefined ones. Both the quality of the products and the way of packaging and marking were investigated.

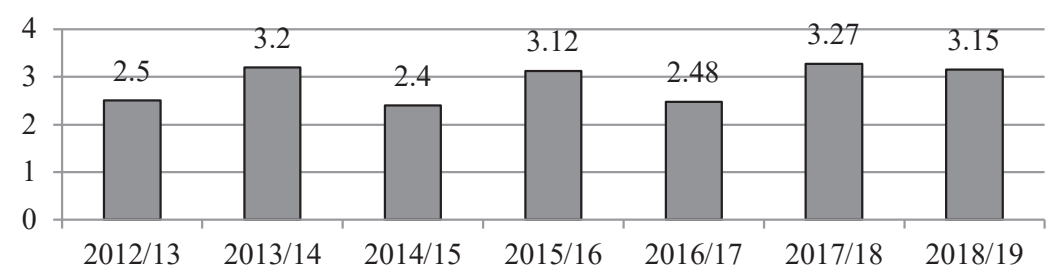

Figure 3. Production volume of olive oil worldwide from 2012/13 to 2018/19 (in millions of tonnes).

Source: Vegetable oils and fats (n.d.). Retrieved from: https://www.statista.com/study/21986/vegetable-oils-and-fatsstatista-dossier. 
Laboratory testing of the quality of oils and olive oil involves, among others, the determination of free fatty acids, determination of the peroxide value, wax content, composition and content of sterols and di-alcohols, as well as fatty acid composition. The packaging and marking of products must comply with EU regulations and national regulations such as the Act of 11 May 2001 on packaging and packaging waste, as well as industry standards such as Global Standard for Packaging and Packaging Materials created by British Retail Consortium and Institute of Packaging (BRC/IOP standard; http://www.haccppolska.pl/opakowania.html).

In the published report, up to 73 batches (19.2\%) were filed for various types of reservations and they concerned mainly the labeling of unrefined oils other than olive oil. Among the olive oil sold, only 21 lots $(11.8 \%)$ were incorrectly labeled, while in the case of non-refined oils there were 52 batches $(25.7 \%)$. It is significant that the quality parameters of olive oil were not questioned, so laboratory analysis did not show any irregularities. It should be added that in the case of olive oil, Regulation (EEC) No 2568/91 of 1991 on the characteristics of olive oil and olive-residue oil and on relevant methods of analysis applies (OJ L 248).

A detailed qualitative analysis was carried out on 48 batches of non-refined oils, with 9 batches being questioned $(18.8 \%)$. In the tested products, non-compliance with the nutritional declaration was detected (for example, a lower content of omega-3 fatty acids in walnut oil, or a lower content of polyunsaturated fatty acids in rice oil, or a lower content of delta 5-avenasterol in rapeseed oil).

From the consumers' point of view, the possibility of verifying various information given on the packaging is the most important. The assessment of the packaging in terms of compliance with applicable regulations revealed irregularities in 54 batches of products $(14.2 \%)-20$ lots of olive oil and 34 lots of other vegetable oils.

In the case of olive oil, the inspection showed the absence of:

- mandatory recommendation to store the oil in a dark and cool place, or an incorrect recommendation was given to store the oil at room temperature;

- a description of the category with regard to organic virgin olive oil of the highest quality;

- translations of certain information into Polish on olive oil labels;

- mandatory information on the country of origin of olive oil;

- proper presentation of the nutritional value, e.g. per $100 \mathrm{~g}$ instead of $100 \mathrm{ml}$.

Other oils were also examined, and in this case the most frequently found irregularities concerned the presentation of nutritional information, because the producers:

- did not keep the right order of nutrients;

- omitted compulsory elements, such as the content of fat or sugars;

- added information that should not be placed, for example, about the lack of cholesterol, which is animal fat and does not occur in plant products.

The second mistake was the incorrect provision of health information by the producers, e.g. that the oil is rich in vitamin $\mathrm{A}$ and the content of this vitamin was declared $3.3 \mu \mathrm{g}(100 \mathrm{~g})^{-1}$, when according to the regulations, the content should be at least $120 \mu \mathrm{g}$ $(100 \mathrm{~g})^{-1}$. Sometimes the producers declared that oil was a source of vitamins $\mathrm{A}, \mathrm{K}$ and $\mathrm{E}$, without giving the amount of these ingredients. It was also stated on the labels that fat from coconut oil did not contribute

Results of quality control and the correctness of the markings for olive oil and vegetable oils

Table 1

\begin{tabular}{|l|c|c|}
\hline Irregularities & Olive oil & Other oils \\
\hline Wrong quality parameters (lowered values) & $\mathrm{x}$ \\
\hline Incorrect information about storage method & $\mathrm{x}$ & \\
\hline No category for oil & $\mathrm{x}$ & \\
\hline No Polish translation of label content & $\mathrm{x}$ & \\
\hline No country of origin & $\mathrm{x}$ & $\mathrm{x}$ \\
\hline Wrong nutritional value & & $\mathrm{x}$ \\
\hline Wrong order of ingredients & & $\mathrm{x}$ \\
\hline Omitting some information & & $\mathrm{x}$ \\
\hline Giving irrelevant information & & \\
\hline Giving false information & & \\
\hline
\end{tabular}

Source: own study on the basis of Informacja z wyników kontroli jakości handlowej nierafinowanych olejów roślinnych i oliwy z oliwek (Information on the results of commercial quality control of unrefined vegetable oils and olive oil), Warszawa 02.01.2018, DIH-703-1(1)/18/AnŁ Retrieved from https://www.uokik.gov.pl/raporty_z_kontroli_inspekcji_handlowej.php. 
to the growth of adipose tissue, for which there is no medical evidence. Among other irregularities, there was information that the oil was ecological, while it was produced using the industrial method. The audit also identified the lack of a Polish language version of mandatory information, such as the date of minimum durability or the country of origin of agricultural raw materials in the case of an organic product. In a few cases, the lack of documents confirming where the oil was purchased was also discovered, as well as the presence of expired oils (Table 1).

The opening of markets facilitated international trade and currently both national and foreign products can be found in every group of goods. However, the latter needs to come with translated labels, because without it the consumers will not be able to comprehend the information they need (Turner, 1995). Naturally, the current labels will not contain all the possible information and markings, but the consumers need to get reliable information on the features of the product and the process of its production (Tzilivakis et al., 2012), which applies also to vegetable oils.

The presented analysis shows that consumers should pay more attention to issues such as the order of ingredients on the labels, the value of quality parameters, or the declared nutritional values. They should also pay attention to whether the producers provide essential information and, most of all, whether the information is true. Vigilance of consumers should apply even to products registered thanks to a protected designation of origin or traditional specialty, such as Black Forest ham or Koryciński cheese. The inspections carried out by the Trade Inspection show that some of such products can also be questioned, for example, due to too much salt in cured meat or water in hard cheese. Because of this, the consumers have to deduce the information from the foodstuffs labels in their current format. It is quite difficult, as the consumers' knowledge about issues such as balanced diet is relatively poor (Shine, O'Reilly, \& O'Sullivan, 1997). It can be stated here that consumer knowledge about healthy lifestyle and the specificity of particular products is extremely important. On the other hand, the average consumer is not able to verify many of the parameters; therefore, the provisions regulating the production process as well as the labeling of products are of importance.

\section{Conclusions}

In the countries where olive oil is not a traditional product, such as Poland, Germany, or the UK, the consumption of this product has been systematically growing. The consumption of other vegetable oils is also growing, so this group of products is important in the diet of modern people. The purpose of this article was to determine what consumers should know in order to independently verify the correctness of information on foodstuff labels on the example of vegetable oils and olive oil. The conducted analysis of the Polish Trade Inspection's report showed that the producers usually do not give the proper way of storing their product and they wrongly describe the nutritional values thereof. Therefore, the consumers should possess a certain amount of knowledge. In the case of olive oil, the consumers should also know about different categories of olive oil and differences between the Extra Virgin and Virgin oil (different acidity levels). In the case of other oils, the consumers should know about the obligatory information which should be present on product labels and, for instance, on the order of listing the ingredients. They should also be able to verify which information is indispensable, and which is untrue.

Certainly, the average consumer will not be able to verify many elements, such as vitamin content or acidity. However, much can be assessed independently, provided one has basic knowledge on the products they purchase.

\section{References}

1. BRC/IOP standard for packaging and packaging materials. Retrieved March 12, 2019, from http://www. haccp-polska.pl/opakowania.html.

2. Commission Regulation (EEC) No 2568/91 of 11 July 1991 on the characteristics of olive oil and oliveresidue oil and on the relevant methods of analysis. OJ L 248.

3. Crescimanno, M., Di Marco, S., \& Guccione, G. (2002). Production and trade marketing policies regarding organic olive oil in Sicily. British Food Journal, 104(3/4/5), 175-186. DOI: 10.1108/00070700210425642.

4. Giansante, L., Di Loreto, G., Di Serio, M.G., Vito, R., \& Di Giacinto, L. (2017). Commercial extra virgin olive oils: Global Quality Index computation and pattern recognition by chemometrics. British Food Journal, 119(9), 2102-2116. DOI: 10.1108/BFJ-02-2017-0093.

5. Informacja $\mathrm{z}$ wyników kontroli jakości handlowej nierafinowanych olejów roślinnych i oliwy z oliwek (Information on the results of commercial quality control of unrefined vegetable oils and olive oil). (2018). Warszawa 02.01.2018, DIH-703-1(1)/18/AnŁ. Retrieved March 12, 2019, from https://www.uokik.gov.pl /raporty_z_kontroli_inspekcji_handlowej.php. (in Polish) 
6. Kavallari, A., Maas, S., \& Schmitz, M. (2011). Examining the determinants of olive oil demand in nonproducing countries: evidence from Germany and the UK. Journal of Food Products Marketing, 17, 355-372. DOI: 10.1080/10454446.2011.548721.

7. Produkcja soi w Argentynie (Soy production in Argentina). Retrieved March 12, 2019, from https:// argentina.trade.gov.pl /.../argentyna/.../143214,produkcja-soi-w-argentynie.htm. (in Polish)

8. Regulation (EU) No 1151/2012 of the European Parliament and of the Council of 21 November 2012 on quality schemes for agricultural products and foodstuffs. OJ L 343/1.

9. Shine, A., O’Reilly, S., \& O’Sullivan, K. (1997). Consumer attitudes to nutrition labeling. British Food Journal, 99(8), 283-289. DOI: 10.1108/00070709710188381.

10. Turner, A. (1995). Prepacked food labelling: past, present and future. British Food Journal, 97(5), $23-31$. DOI: $10.1108 / 00070709510091047$.

11. Tzilivakis, J., Green, A., Warner, D., McGeevor, K., \& Lewis, K. (2012). A framework for practical and effective Eco-labelling of food products. Sustainability Accounting, Management and Policy Journal, 3(1), 50-73. DOI: 10.1108/20408021211223552.

12. Vegetable oils and fats. Retrieved March 12, 2019, from https:/www.statista.com/study/21986/vegetableoils-and-fats-statista-dossier.

13. Zajaczkowski, M. (2002). Produkt i cena w marketing współczesnym (Product and price in modern marketing). Szczecin, Wyd. Akademii Rolniczej w Szczecinie. (in Polish) 